Supplement of Nat. Hazards Earth Syst. Sci., 19, 2421-2449, 2019

https://doi.org/10.5194/nhess-19-2421-2019-supplement

(c) Author(s) 2019. This work is distributed under

the Creative Commons Attribution 4.0 License.

(c) (1)

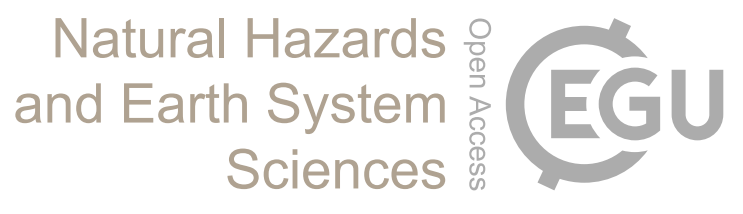

Supplement of

\title{
Mapping the susceptibility of rain-triggered lahars at Vulcano island (Italy) combining field characterization, geotechnical analysis, and numerical modelling
}

Valérie Baumann et al.

Correspondence to: Costanza Bonadonna (costanza.bonadonna@unige.ch)

The copyright of individual parts of the supplement might differ from the CC BY 4.0 License. 


\section{Supplementary material}

\section{Section 1: example of a recent lahar (September 2017 lahar)}

A small lahar event occurred in September 2017, one month before our 2017 field work. The lahar source area was located on the NW cone flank in a funnel shaped area located above a small gully at an elevation of $159 \mathrm{~m}$ above sea level. The lahar flowed into a gully with an average width of 2 meter and a depth varying between 0.4 and $0.8 \mathrm{~m}$ (Fig. S1), formed levees on both sides and stopped on the La Fossa crater trail with a final runout of $120 \mathrm{~m}$. The area of the front lobe deposit was measured with a handheld GPS $\left(135.5 \mathrm{~m}^{2}\right)$ and approximate thickness estimated $(0.3 \mathrm{~m})$ in the field, which resulted in a volume of $\sim 40 \mathrm{~m}^{3}$. A second lahar flow pulse deposited a small deposit confined within the channel (Fig. S2). Two samples (V11 and V12) were taken from this recent lahar deposit in order to compare with the older lahar deposits.
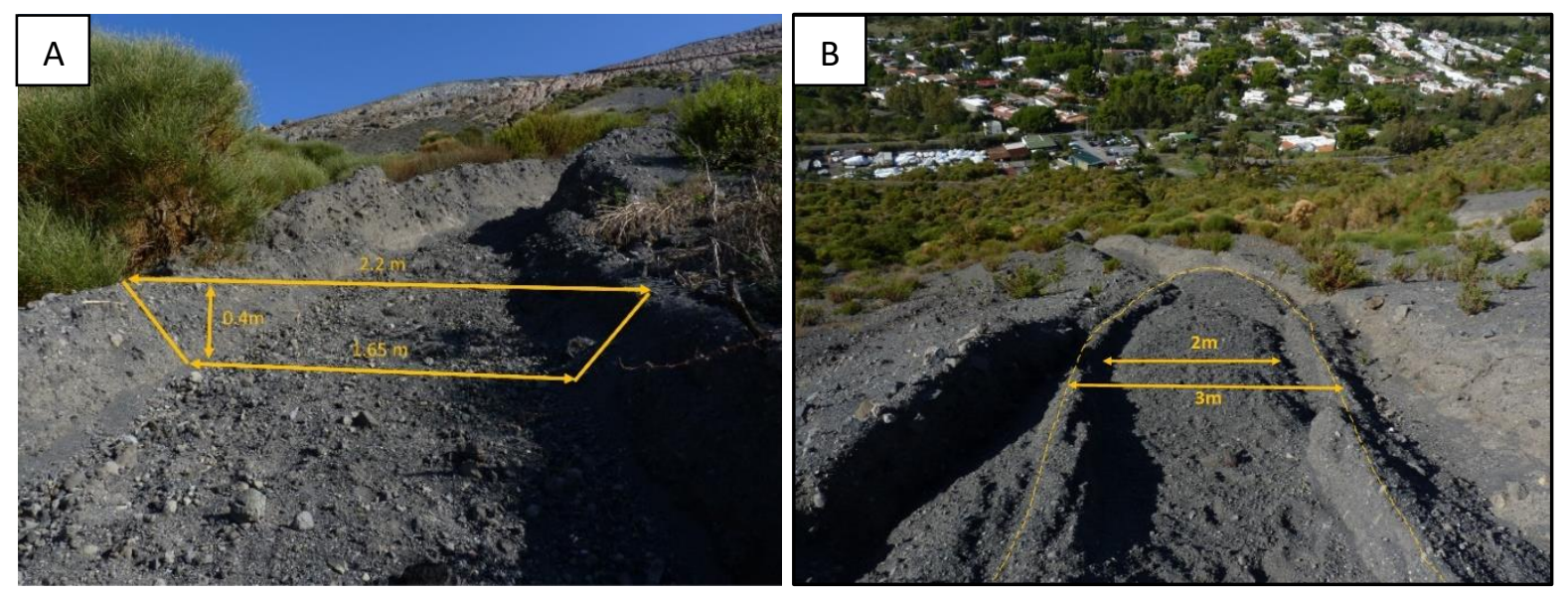

Figure S1: A) September 2017 lahar gully; B) September 2017 lahar deposit confined within the channel; the yellow lines mark the levee and the contour of the deposit. 


\section{Section 2: tephra-fallout and lahar properties}

In this section the grainsize distribution of both tephra-fallout and lahar samples are shown (Fig. S3). Tables S1 and S2 describe the associated suction, thickness, slope angle and grainsize characteristics.
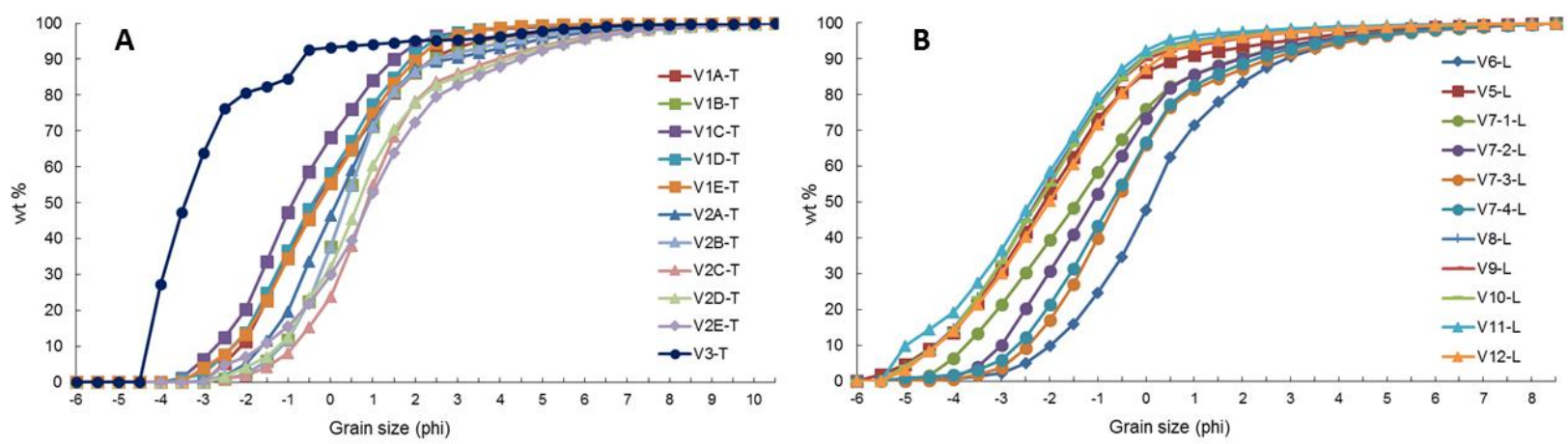

Figure S3: Grainsize distribution for A) primary and B) remobilised deposits (lahars). See Table S2 for a reference of sample numbers.

Table S1: Suction measured in the field on the 1888-90 tephra-fallout deposit and Md $\phi$ for Su5 and Su7 (Fig. 1, main text). NA = Not available

\begin{tabular}{lll}
\hline Location & $\begin{array}{l}\text { Suction } \\
(\mathbf{k P a})\end{array}$ & Md $\boldsymbol{}$ \\
\hline Su1 & 25 & NA \\
Su2 & 24 & NA \\
Su3 & 27 & NA \\
Su4 & 14 & NA \\
Su5/V01 & 15 & -0.27 \\
Su6 & 15 & NA \\
Su7/V08 & 20 & 0.90 \\
\hline
\end{tabular}


Table S2: Summary of the physical characteristics of the tephra-fallout and lahar samples analysed. 30*: slope is measured on GIS (Geographic Information System). Thick. refers to the total deposit thickness. Unit refers to the 1888-1890 eruption (1888-90), the Palizzi D eruption (Pal D) and lahars. For section V1 and V2, the horizon shows the sampled section interval. F1 and $F 2$ refers to the weight sample fraction $<1 \mathrm{~mm}$ and $<63 \mu \mathrm{m}$, respectively.

\begin{tabular}{|c|c|c|c|c|c|c|c|c|c|}
\hline Site & Section & Name & $\begin{array}{l}\text { Thick. } \\
\text { (cm) }\end{array}$ & Horizon & slope $\left(^{\circ}\right)$ & $\operatorname{Md} \varphi$ & $\sigma \varphi$ & F1 & $\mathbf{F 2}$ \\
\hline unit & \multicolumn{9}{|c|}{$1888-90$ tephra-fallout deposit } \\
\hline \multirow{5}{*}{ S La fossa cone } & \multirow{5}{*}{ V1 } & V1A & 100 & $0-6$ & 30 & -0.37 & 1.80 & 35.13 & 3.23 \\
\hline & & V1B & 100 & $6-12$ & 30 & 0.08 & 1.46 & 39.99 & 2.60 \\
\hline & & V1C & 100 & $12-18$ & 30 & -0.88 & 1.63 & 24.03 & 1.22 \\
\hline & & V1D & 100 & $18-24$ & 30 & -0.41 & 1.68 & 32.81 & 0.84 \\
\hline & & $\mathrm{V} 1 \mathrm{E}$ & 100 & $24-30$ & 30 & -0.27 & 1.71 & 35.26 & 0.83 \\
\hline \multirow{5}{*}{$\begin{array}{l}\text { NW La fossa cone } \\
\text { base }\end{array}$} & \multirow{5}{*}{$\mathrm{V} 2$} & V2A & 50 & $0-6$ & 10 & 0.14 & 1.49 & 40.81 & 5.63 \\
\hline & & V2B & 50 & $6-12$ & 10 & 0.09 & 1.78 & 44.97 & 4.13 \\
\hline & & $\mathrm{V} 2 \mathrm{C}$ & 50 & $12-18$ & 10 & 0.85 & 1.51 & 62.09 & 7.86 \\
\hline & & V2D & 50 & $18-24$ & 10 & 0.66 & 1.80 & 54.66 & 8.68 \\
\hline & & $\mathrm{V} 2 \mathrm{E}$ & 50 & $24-30$ & 10 & 0.90 & 2.10 & 60.41 & 9.71 \\
\hline unit & \multicolumn{9}{|c|}{ Pal D tephra-fallout deposit } \\
\hline Pallizi valley & V3 & V3 & 25 & - & 10 & -3.42 & 1.55 & 6.31 & 2.83 \\
\hline unit & \multicolumn{9}{|c|}{ Lahar deposit } \\
\hline Pallizi valley & V6 & V6 & 15 & - & 5 & 2.07 & 1.78 & 84.12 & 12.38 \\
\hline S La Fossa cone & V5 & V5 & 15 & - & 30 & -0.12 & 1.83 & 37.46 & 5.73 \\
\hline \multirow{4}{*}{ Porto di Ponente } & \multirow{4}{*}{ V7 } & V7A & 26 & - & $0-3$ & 0.58 & 2.04 & 51.65 & 7.71 \\
\hline & & V7B & 11 & - & $0-3$ & 0.90 & 1.75 & 58.91 & 7.87 \\
\hline & & V7C & 10 & - & $0-3$ & 1.38 & 1.73 & 72.86 & 10.31 \\
\hline & & V7D & 6 & - & $0-3$ & 1.29 & 1.76 & 68.65 & 8.92 \\
\hline \multirow{5}{*}{ NW La fossa cone } & V8 & V8 & 30 & - & $30 *$ & -0.29 & 1.67 & 33.27 & 2.51 \\
\hline & V9 & V9 & 40 & - & 30 & -0.27 & 1.69 & 34.04 & 3.29 \\
\hline & V10 & V10 & 30 & - & 30 & -0.24 & 1.68 & 34.02 & 2.85 \\
\hline & V11 & V11 & 20 & - & $25^{*}$ & -0.40 & 1.82 & 31.68 & 1.89 \\
\hline & V12 & $\mathrm{V} 12$ & 20 & - & $25^{*}$ & -0.02 & 1.82 & 39.42 & 3.16 \\
\hline
\end{tabular}

